\title{
Relationship between body condition score and subcutaneous fat and muscle area measured by ultrasound in Pelibuey ewes
}

\author{
Alfonso J. Chay-Canul' ${ }^{1}$, Ricardo A. Garcia-Herrera ${ }^{1 *}$, Nadia F. Ojeda-Robertos ${ }^{1}$, Ulises Macias-Cruz ${ }^{2}$, \\ Ricardo Vicente-Pérez ${ }^{3}$, Víctor M. Meza-Villalvazo ${ }^{4}$ \\ ${ }^{1}$ División Académica de Ciencias Agropecuarias, Universidad Juárez Autónoma de Tabasco, Carretera Villahermosa-Teapa, km 25, R/A, La \\ Huasteca $2^{a}$ Sección, CP 86280, Villahermosa, Tabasco, México, Tel. (993) 358-1585, 142-9151, Fax: (993) 142-9150, ${ }^{2}$ Instituto de Ciencias \\ Agrícolas, Universidad Autónoma de Baja California, Ejido Nuevo León S/N, Mexicali, B.C., CP. 21705, México, ${ }^{3}$ Departamento de Producción \\ Agrícola, Centro Universitario de la Costa Sur, Universidad de Guadalajara, Autlán de Navarro, Jalisco, 48900, México, ${ }^{4}$ Universidad del \\ Papaloapan, Instituto de Biotecnología, Circuito Central No. 200, Col, Parque Industrial. CP. 68301, Tuxtepec, Oaxaca, México
}

\section{A B S T R A C T}

\begin{abstract}
The body condition score (BCS) is the main measure used to determine nutritional and body status in the sheep industry, however, its evaluation is subjective and, both researchers and producers can easily fall into an overestimate or underestimate of this parameter. In consequence, this study aimed to assess if back fat thickness (FT) and Longissimus dorsi area (LDA) measured by ultrasonography can be used to develop prediction equations for BCS in multiparous and non-pregnant Pelibuey ewes. Eighty ewes were used to carry out the experiment. Experienced technicians developed the evaluation of BCS using a 5 point scale, as well as the measurements of FT and LDA in the thoracic and lumbar regions with real-time ultrasound equipment. The FT in the thoracic and lumbar regions ranged from 0 to $5.50 \mathrm{~mm}$ and the thoracic and lumbar LDA varied from 2.96 to $13.00 \mathrm{~cm}^{2}$. BCS had a positive moderate correlation $(P<0.0001)$ with thoracic and lumbar FT $(0.45 \leq r \leq 0.60)$, as well as with thoracic and lumbar LDA $(0.65 \leq r \leq 0.67)$. Simple linear regression equations for BCS showed to be significant $(<0.0001)$ using ultrasound measurements as predictors, being a better predictor LDA $\left(r^{2}=0.92\right)$ than FT $\left(r^{2}=0.21-0.36\right)$. Using multiple linear regression, the equation that included lumbar FT and LDA as independent variables showed to be the best $\left(r^{2}=0.93, \mathrm{MSE}=0.76\right.$ and $\left.\mathrm{RSD}=0.87\right)$ to predict $\mathrm{BCS}$. In conclusion, ultrasound measurements may be used to predict BCS, mainly LDA, in multiparous and non-pregnant Pelibuey ewes.
\end{abstract}

Keywords: Ewes; Sheep production; Fat deposition; Ultrasound measurements

\section{INTRODUCTION}

The population of hair breed sheep has been increasing gradually in the last decade across the American continent, and their distribution is not limited to tropical regions as before. Actually, hair breed sheep are dispersed both in tropical regions as template and arid, and they have shown good adaptation to these environmental conditions (McManus et al., 2010). Sheep from Pelibuey breed or their crosses with Dorper and Katahdin are the main hair genotypes distributed in Mexico, and its production system is most extensive in natural fodder (Chay-Canul et al., 2011). Consequently, the evaluation of the nutritional status of animals from its body structure has great importance into the farm management to maintain adequate productive and reproductive efficiency (McManus et al., 2010). So, a continuous assessment of the body status in the sheep is required to establish nutritional management strategies in flocks.

The body condition score (BCS) has been used as an index of available body energy reserves in domestic and farm animals and is widely used in ewes (Russel et al., 1969; Chay-Canul et al., 2011; Kenyon et al., 2014). The BCS is a method easy to perform and does not require any particular equipment for its measurement (Mendizabal et al., 2011, Kenyon et al., 2014); however, this measurement is considered to be subjective to some extent (Chay-Canul et al., 2016), and therefore, its reliability and validity have

\footnotetext{
${ }^{*}$ Corresponding author:

Ricardo A. Garcia-Herrera, División Académica de Ciencias Agropecuarias, Universidad Juárez Autónoma de Tabasco, Carretera

Villahermosa-Teapa, km 25, R/A, La Huasteca 2a Sección, CP 86280, Villahermosa, Tabasco, México, Tel. (993) 358-1585, 142-9151,

Fax: (993) 142-9150. E-mail: ricardogarciaherrera@hotmail.com
}

Received: 01 December 2018;

Accepted: 25 January 2019 
been questioned (Zulu et al., 2001; Keinprecht et al. 2016). For this reason, it has been evaluated other methods such as ultrasound, the use of digital images and recently using Smartphone Applications (Schröder and Staufenbiel, 2006, Azzaro et al. 2011, Halachmi et al. 2013; Chay-Canul et al., 2016; Alic-Ural 2016).

Studies done in dairy cows (Schröder and Staufenbiel, 2006; Hussein et al., 2013) have reported that measurements of backfat thickness (FT) by ultrasonography along with the BCS can be used to assess the energetic and body state in this species. Also, a good positive correlation has been observed between BCS and ultrasound measurements in cows (Zulu et al., 2001; Broring et al., 2003), horses (Silva et al., 2016), donkey (Quaresma et al., 2013) and hair breed sheep (Chay-Canul et al., 2016). For their part, Junkuszew and Ringdorfer (2005) found that ultrasound measurements (subcutaneous fat and muscle depth) were positively correlated with the body composition of wool breed lambs. Thus, ultrasound measurements as FT and area of the Longissimus dorsi muscle (LDA) have proved to be useful to develop prediction equations for BCS in cattle and sheep.

The use of prediction equations including FT and LDA measured by ultrasound as predictor variables could be an alternative to objectively assess BCS in hair sheep breeds. However, the information on the relationship between BCS and ultrasound measurements from fat and muscle tissue is limited, and in consequence, the evaluation of FT and LDA as predictor variables for BCS has not been done in these hair sheep breeds. Thus, the objective of the present study was to assess if backfat thickness and Longissimus dorsi muscle area measured by ultrasonography can be used to develop prediction equations for BCS in multiparous and non-pregnant Pelibuey ewes.

\section{MATERIALS AND METHODS}

\section{Animals and management}

The experiment was conducted at the "El Rodeo" farm $\left(17 \mathrm{o} 84^{\prime} \mathrm{N}, 92 \mathrm{o} 81^{\prime} \mathrm{W}\right)$, located in the Villahermosa township, Tabasco State, in the Southeast region of Mexico. The climate in the region is warm-humid, with average minimum and maximum temperature of $18.5^{\circ}$ and $36^{\circ} \mathrm{C}$, and an annual precipitation of $2299.5 \mathrm{~mm}$ (CONAGUA 2016). All procedures involving animals were conducted within the guidelines of official techniques of animal care and health in México (NOM-051-ZOO-1995).

A total of 80 non-pregnant and non-lactating Pelibuey ewes (age $=2-3$ years old, body weight $=39.0 \pm 7.5 \mathrm{~kg}$ and $\mathrm{BCS}=3.1 \pm 1.2$ units) were used. Ewes were confined in pens equipped with concrete floor, shade, and feed and drinking troughs. The diet offered was formulated with a forage: concentrate ratio of $66: 34 \%$ to provide $12 \mathrm{MJ}$ of metabolizable energy $/ \mathrm{kg}$ dry matter and $10 \%$ of crude protein to ewes (AFRC, 1993). In general, the dietary ingredients were ground corn (19\%), soybean meal (11\%), cane molasses $(3 \%)$, hay of star grass $(66 \%)$, vitamins, and minerals $(1 \%)$.

\section{Ultrasound and BCS measurements}

The BCS for each ewe was evaluated by two experienced technicians, using a 1-5 scale, with 0.5 increments; where BCS 1 represents a thin animal and 5 an obese animal as described by Russel et al. (1969). The ultrasound measurements were determined using an Aloka 500 real-time ultrasound machine in B-mode, equipped with a $5 \mathrm{MHz}$ linear probe (Corometrics Medical Systems, Wallingford, CT). Ewes were shaved previously between the $12^{\text {th }}$ and $13^{\text {th }}$ thoracic vertebrae and the $3^{\text {rd }}$ and $4^{\text {th }}$ lumbar vertebrae regions according to Aguilar-Hernandez et al. (2016) and Chay-Canul et al. (2016). The measurements carried were FT (mm) and LDA $\left(\mathrm{cm}^{2}\right)$ both in thoracic (TFT and TLDA) and lumbar region (LFT and LLDA). The ewes were manually immobilized; an acoustic gel was used to create good contact between the probe and the skin of ewes. The pressure over the transducer head was kept to a minimum to avoid compression of the subcutaneous fat (AguilarHernandez et al. 2016; Chay-Canul et al. 2016). All measurements were taken on the left side of ewes and by the same operator following the methodology described by Aguilar-Hernandez et al. (2016) and Chay-Canul et al. (2016). After capturing the scan image, the LDA and FT in both regions were measured using the digital callipers of the equipment to record the information for each animal.

\section{Data analysis}

A descriptive statistical analysis for BCS and ultrasound measurements was performed using the PROC MEANS of SAS (SAS 2010). The data of ultrasound measurements were analyzed using a linear model with BCS group as a fixed effect using the PROC GLM of SAS (SAS 2010). Pearson's correlation coefficients among variables were estimated using the PROC CORR of SAS (SAS, 2010). Relationships between BCS and ultrasound measurements were estimated by linear regression models using PROC REG of SAS (SAS Ver. 9.3, 2010). The option STEPWISE and Mallow's Cp were used in the SELECTION statement for significant $(\mathrm{P}<0.05)$ variables to be included in the models. The accuracy of the models was evaluated by the determination coefficient $\left(\mathrm{r}^{2}\right)$, means square error (MSE) and univariate linear regression analysis comparing predicted and observed values. 


\section{RESULTS}

Predominantly the ewes used in this study had a BCS between 3.0 and 4.0 units (53.7\%), and only $31.3 \%$ and $17.5 \%$ of ewes recorded BCS $<3.0$ units and $>4.0$ units, respectively. Results of the descriptive analysis are shown in Table 1. The TFT and LFT values ranged from 0.1 to $5.50 \mathrm{~mm}$, while the TLDA and LLDA values varied from 2.96 to $13.00 \mathrm{~cm}^{2}$. Coefficients of variation for all variables were above $29 \%$.

Results of the effect of BCS on ultrasound measurements are shown in Table 2. Ewes with BCS $<3.0$ units had lower $(\mathrm{P}<0.0001)$ FT and LDA both in the thoracic and lumbar region than ewes with BCS $>3.0$ units. Additionally, ewes with BCS $=5.0$ units showed higher $(\mathrm{P}<0.0001)$ TLDA and LLDA than ewes with BCS $=3.0$ or 4.0 units. The TFT and LFT did not vary among ewes with BCS $>3.0$ units.

Results of Person's correlations are shown in Table 3. BCS was positively correlated $(P<0.0001)$ with ultrasound measurements, although the relationship between these variables was considered as moderate $(0.45 \leq \mathrm{r} \leq 0.67)$. Also, TFT, LFT, TLDA and LLDA showed a positive correlation $(P<0.0001 ; 0.44 \leq \mathrm{r} \leq 0.85)$, highlighting the correlation between TLDA and LLDA $(\mathrm{r}=0.85)$.

The linear regression equations developed between BCS and ultrasound measurements are shown in Table 4. Simple linear regression equations showed a positive association $(P<0.0001)$ between BCS and ultrasound measurements, but the determination coefficients were low with TFT $\left(\mathrm{r}^{2}=\right.$ 0.21 ; Eq. 1) and LFT as independent variables $\left(r^{2}=0.36\right.$; Eq. 4). Contrary, high determination coefficients were observed with TLDA ( $r^{2}=0.92$; Eq. 3$)$ and LLDA $\left(r^{2}=0.92\right.$; Eq. 6$)$ as independent variables. It should be mentioned that the intercept was not significant for equations where TLDA (Eq. 2) and LLDA (Eq. 5) were considered as independent variables, so these equations were fitted for simple linear regressions through the origin (Eq. 3 and 6). In the multiple linear regression analysis, the best model to predict BCS considered LFT and LLDA as predictor variables (Eq. 7). Nonetheless, because the intercept of the equation 7 also was not significant, we fitted a multiple linear regression through the origin in this model (Eq. 8; $P<0.001, \mathrm{r}^{2}=0.93$, $\mathrm{MSE}=0.76$ and $\mathrm{RSD}=0.87)$.

Results of comparison of predicted and observed values for BCS are shown in Fig. 1. Predicted and observed BCS agree $(P<0.001)$ when equations 3,6 and 8 were used to obtain predicted values. The $\mathrm{r}^{2}$ values in these analyses ranged from 0.43 to 0.52 , by which these equations that included TLDA, LLDA or LLDA and LFT can predict BCS with a moderate accuracy in Pelibuey ewes.

\section{DISCUSSION}

This study aimed to stablish the relationships of back fat thickness (FT) and L. dorsi muscle area (LDA) determined by ultrasound with BCS in non-pregnant, non-lactating and multiparous Pelibuey ewes. Several papers have been published on this topic in other species (Ayres et al., 2009; Quaresma et al., 2013; Hussein et al., 2013; Silva et al., 2016), while this study seems to be the first one involving a tropical sheep breed. Mean values for TFT (1.2 vs. $2.0 \mathrm{~mm})$, LFT (1.3 vs. $1.9 \mathrm{~mm}$ ), TLDA (6.9 vs. $7.1 \mathrm{~cm}^{2}$ ) and LLDA $\left(6.6\right.$ vs. $\left.6.9 \mathrm{~cm}^{2}\right)$ were slightly below than those reported by Aguilar-Hernández et al. (2016) and Chay-Canul et al. (2016) for this type of Pelibuey ewes. Additionally, ewes of the current study were $8 \%$ more weighted and with higher BCS variation (1-5 vs. 1.5-3.5 units) than ewes from previous studies (Aguilar-Hernández et al., 2016; Chay-Canul et al.

Table 1: Mean values, range of values, standard deviation error (SD) and coefficient of variation (CV) of BCS and ultrasound measurements in Pelibuey ewes $(n=80)$

\begin{tabular}{|c|c|c|c|c|c|}
\hline Variable & Description & Mean \pm SD & Maximum & Minimum & CV \\
\hline BCS & Body condition score (units) & $3.07 \pm 1.25$ & 5.00 & 1.00 & 40.33 \\
\hline TFT & Thoracic fat thickness $(\mathrm{mm})$ & $1.25 \pm 0.83$ & 3.40 & 0.1 & 66.40 \\
\hline TLDA & Thoracic L. dorsi area $\left(\mathrm{cm}^{2}\right)$ & $6.86 \pm 2.05$ & 12.95 & 2.96 & 29.88 \\
\hline LFT & Lumbar fat thickness (mm) & $1.32 \pm 0.95$ & 5.50 & 0.1 & 71.97 \\
\hline LLDA & Lumbar L. dorsi area $\left(\mathrm{cm}^{2}\right)$ & $6.56 \pm 2.01$ & 3.30 & 13.00 & 30.64 \\
\hline
\end{tabular}

Table 2: The least-square mean values of ultrasound measurements by effect of the body condition score in Pelibuey ewes

\begin{tabular}{|c|c|c|c|c|c|c|}
\hline & \multicolumn{5}{|c|}{ Body condition score (units) } & \multirow[t]{2}{*}{$P$-value } \\
\hline & 1.0 & 2.0 & 3.0 & 4.0 & 5.0 & \\
\hline TFT & $0.30^{\mathrm{a}} \pm 0.20$ & $0.78^{\mathrm{a}} \pm 0.18$ & $1.69^{b} \pm 0.13$ & $1.38^{b} \pm 0.16$ & $1.58^{b} \pm 0.19$ & $<0.0001$ \\
\hline TLDA & $4.79^{\mathrm{a}} \pm 0.44$ & $5.54^{\mathrm{a}} \pm 0.39$ & $7.12^{b} \pm 0.29$ & $6.84^{b} \pm 0.34$ & $9.76^{c} \pm 0.42$ & $<0.0001$ \\
\hline LFT & $0.35^{\mathrm{a}} \pm 0.22$ & $0.55^{\mathrm{a}} \pm 0.19$ & $1.62^{\mathrm{b}} \pm 0.14$ & $1.48^{\mathrm{b}} \pm 0.17$ & $2.23^{b} \pm 0.21$ & $<0.0001$ \\
\hline LLDA & $4.60^{\mathrm{a}} \pm 0.39$ & $4.93^{\mathrm{a}} \pm 0.35$ & $6.93^{b} \pm 0.26$ & $6.76^{b} \pm 0.30$ & $8.90^{\circ} \pm 0.37$ & $<0.0001$ \\
\hline
\end{tabular}

TFT: Thoracic fat thickness; LFT: Iumbar fat thickness; TLDA: Thoracic L. dorsi area, LLDA: Lumbar L. dorsi area a,b,c Values within row with different superscripts are different at $\mathrm{P}<0.05$ 
(2016). Therefore, the variations in mean values for FT and LDA could be attributed to differences in the BCS range, diet, and/or environmental factors. Moreover, the values of standard deviation showed that data of FT were more dispersed around the mean than data of LDA, which it is congruent with finds of other studies done in sheep (Aguilar-Hernández et al., 2016). There are evidences in the literature suggesting that malnutrition scenario in adult ewes is greatly reflected in rapid alterations on the fat tissue deposition, while muscle tissue is less affected (Chay-Canul et al., 2011); this is product of metabolic adaptations that

Table 3: Correlation coefficients among body condition score (BCS), thoracic fat thickness (TFT), lumbar fat thickness (LFT), thoracic $L$. dorsi area (TLDA) and lumbar L. dorsi area (LLDA) in Pelibuey ewes

\begin{tabular}{|c|c|c|c|c|}
\hline Variable & BCS & TFT & TLDA & LFT \\
\hline TFT & $0.45^{\star \star \star}$ & & & \\
\hline TLDA & $0.65^{\star \star \star}$ & $0.44^{\star * *}$ & & \\
\hline LFT & $0.60^{\star \star \star}$ & $0.71^{* \star *}$ & $0.56^{\star \star \star}$ & \\
\hline LLDA & $0.67^{* \star *}$ & $0.46^{* * *}$ & $0.85^{\star \star *}$ & $0.58^{\star * *}$ \\
\hline
\end{tabular}

${ }^{* * *} \mathrm{P}<0.0001$. BCS: Body condition score; TFT: thoracic fat thickness; LFT: lumbar fat thickness; TLDA: Thoracic $L$. dorsi area; LLDA: Lumbar L. dorsi area. development any ruminant to survive (Chilliard et al., 1998). In this sense, higher variation in TFT and LFT compared to TLDA and LLDA was expected.

Ewes with low BCS (<3.0 units) had decreased FT and LDA both in the thoracic and lumbar region. This situation is well documented in the literature; low BCS in sheep is a reflection of undernutrition, and consequently, ewes under such nutritional scenario mobilize fat and muscle tissue to compensate its energetic deficit (Chillard et al., 1998). Interestingly, ewes with BCS $=5.0$ units had higher LDA but not FT compared with ewes with BCS=3.0 and 4.0 units. This suggests that BCS in the current study was overestimated in apparently fat ewes (BCS $=5.0$ units). While it is true that the BCS evaluation using the methodology of Russel et al. (1969) is easy and reflects with certain precision the corporal state of the sheep, our results demonstrate that experienced evaluators can present problems to differentiate between Pelibuey ewes with 3 or more of BCS.

According to Taylor (1990), the BCS in Pelibuey ewes showed a moderate association $(0.36 \leq \mathrm{r} \leq 0.67)$ with FT

Table 4: Linear regression equations between BCS and ultrasound measurements in Pelibuey ewes $(n=80)$

\begin{tabular}{|c|c|c|c|c|c|c|c|c|c|}
\hline Equations & $a \pm S E$ & TFT $\pm S E$ & TLDA $\pm S E$ & LFT $\pm S E$ & LLDA $\pm S E$ & $\mathbf{R}^{2}$ & MSE & RSD & $P$-value \\
\hline 1 & $2.20 \pm 0.22^{* * *}$ & $0.69 \pm 0.15^{\star * \star}$ & & & & 0.21 & 1.24 & 1.11 & $<0.0001$ \\
\hline 2 & $0.34 \pm 0.37^{\mathrm{ns}}$ & & $0.39 \pm 0.05^{\star \star *}$ & & & 0.43 & 0.90 & 0.95 & $<0.0001$ \\
\hline 3 & & & $0.44 \pm 0.01^{\star * *}$ & & & 0.92 & 0.90 & 0.95 & $<0.0001$ \\
\hline 4 & $2.03 \pm 0.19^{\star * \star}$ & & & $0.78 \pm 0.11^{\star *}$ & & 0.36 & 1.00 & 1.00 & $<0.0001$ \\
\hline 5 & $0.12 \pm 0.37^{\mathrm{ns}}$ & & & & $0.45 \pm 0.05^{\star \star \star}$ & 0.46 & 0.85 & 0.92 & $<0.0001$ \\
\hline 6 & & & & & $0.47 \pm 0.01^{* * *}$ & 0.92 & 0.84 & 0.91 & $<0.0001$ \\
\hline 7 & $0.37 \pm 0.36^{\mathrm{ns}}$ & & & $0.41 \pm 0.12^{* *}$ & $0.33 \pm 0.06^{* *}$ & 0.53 & 0.75 & 0.87 & $<0.0001$ \\
\hline 8 & & & & $0.38 \pm 0.12^{\star *}$ & $0.39 \pm 0.02^{\star \star *}$ & 0.93 & 0.76 & 0.87 & $<0.0001$ \\
\hline
\end{tabular}

$\mathrm{R}^{2}$ : coefficient of determination; MSE: Mean Square Error; RSD: Residual Standard deviation; SE: Standard Error; BCS: body condition score; TFT: thoracic

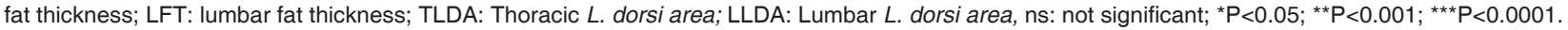
${ }^{1}$ Intercepts that were not different from 0 were removed from the final equation

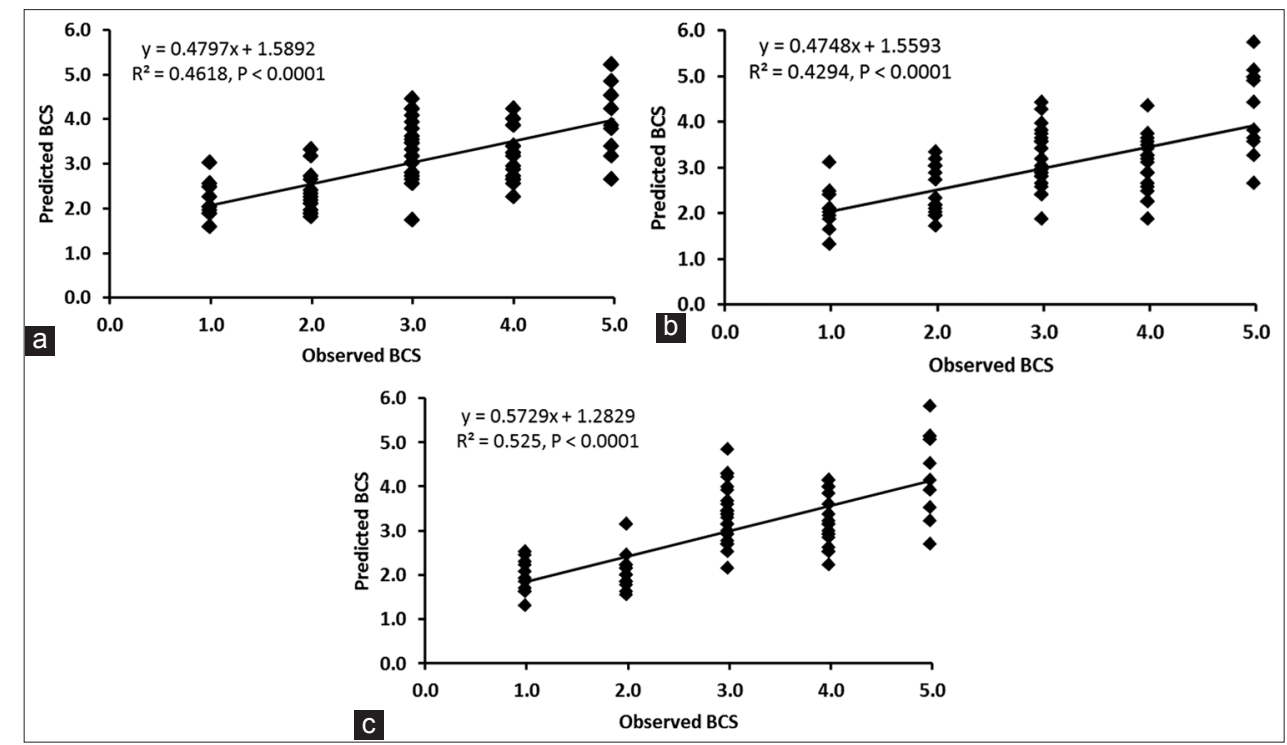

Fig 1. Relationship between predicted and observed body condition score (BCS) using the equations 3 (A, thoracic L. dorsi area), 6 (B, lumbar L. dorsi area) and 8 (C, L. dorsi area and fat thickness in lumbar region). 
and LDA; so these ultrasound measurements can be used to predict the BCS through linear regression models in multiparous and non-pregnant Pelibuey ewes. Notably, TLDA, LLDA and LFT ( $\mathrm{r}=0.60$ to 0.67 ) could be better predictors for BCS than TFT $(r=0.45)$. However, given the values of correlation coefficients, it is difficult to expect that the models developed predict BCS with high accuracy. Consistent with these finding, previous studies have also reported an association between BCS and ultrasound measurements in Pelibuey ewes of similar physiological state and age to those used in the present study (Aguilar-Hernández et al., 2016; Chay-Canul et al., 2016). Additionally, studies done in dairy cows (Schröder and Staufenbiel, 2006; Hussein et al., 2013), Zebu beef cow (Ayres et al., 2009), donkeys and horses (Gentry et al., 2004; Quaresma et al., 2013; Silva et al., 2016) have also indicated a positive relationship between BCS and FT. For its part, Jaurena et al. (2005) found a positive association between BCS and LDA in dry and lactating dairy cows. In all those studies, the correlations $(r \geq 0.40)$ were from moderate to strong, which suggests in combination with our results that ultrasound measurements of muscle and fat in loin are closely related to the body state of the animals.

The FT from the thoracic and lumbar regions showed to be poor predictors for BCS in the Pelibuey ewes of this study, as they explained less than $36 \%$ of the variation observed in the BCS. Chay-Canul et al. (2016) found also an association $\left(0.38 \leq r^{2} \leq 0.43\right)$ between BCS and FT measured by ultrasound but low using simple linear regression in adult and non-pregnant Pelibuey ewes. However, in a work done with Rasa Aragonesa ewes indicated that BCS and FT (measured by ultrasound) explained 77 and $65 \%$, respectively, of the variation observed in subcutaneous fat (Mendizabal et al., 2003); in consequence, in this study it was expected a strong relationship between BCS and FT, as well as, a higher $r^{2}$ value in the regression models where TFT and LFT were used as independent variables. So while FT can be used to predict BCS in some sheep breeds as the Rasa Aragonesa and cattle (Broring et al., 2003; Hussein et al., 2013), in Pelibuey breed ewes is not possible.

On the hand, the development of BCS prediction model in domestic (Broring et al., 2003; Hussein et al., 2013, Chay-Canul et al., 2016) and non-domestic (Alapati et al., 2010, Silva et al., 2016) animals have been addressed to use FT ultrasound measurements as predictor variables. The LDA, which can also be measured with ultrasound, has received little attention as a predictor of the BCS. In this study, TLDA and LLDA showed to be good predictors for BCS $\left(r^{2}=0.92\right)$ in the Pelibuey breed, which agrees with results of Sanson et al. (1993), who observed that BCS explained $84 \%$ of the variation in LDA measured directly on the carcass. In fact, the regression analysis between predicted and observed values of BCS showed coincidence between them, with $\mathrm{r}^{2}=0.43$ (TLDA) and 0.46 (LLDA). These values of determination coefficient suggest that TLDA and LLDA could be used to predict BCS with moderate accuracy using the equations 3 and 6 , respectively (Myers 1990). Including other ultrasound measurements in combination with LDA might increase the accuracy of prediction models for BCS.

A multiple linear regression analysis was also applied to the data to verify if a model including both FT and LDA is the best predictor of BCS in Pelibuey ewes. This new model had as predictors to LFT and LLDA $\left(r^{2}=0.92\right.$, Eq. 8), and showed to predict BCS with a moderate accuracy $\left(r^{2}=0.52\right)$. Given the little contribution of LFT to explain the BCS variation in this multiple regression models, we recommended only the use of LDA measured by ultrasonography as the predictor of the BCS in multiparous and non-pregnant Pelibuey ewes. Previous studies were not found in relation to the development of BCS prediction model using a multiple linear regression in sheep, however, Ptáček et al. (2014) mention that sheep BCS as a nutritional status and body development is formed not only by fat reserves but by muscle also. This can be confirmed with our results.

\section{CONCLUSION}

While BCS and FT were poorly correlated, the LDA proved to be a good predictor of the BCS in multiparous and nonpregnant Pelibuey ewes. Therefore, LDA can be used to develop prediction equations for BCS, and thus, the BCS evaluation could be measured objectively in sheep flocks of the hair breeds, or at least in pure Pelibuey and their crosses. It should be noted that the use of this tool for management in commercial flocks could be impractical, since the equipment is expensive and a qualified technician is needed. However, at experimental level in studies of nutrition or nutrition-reproduction interaction, the determination of LDA by ultrasound together with the BCS traditional could be of great help to improve the interpretation of results.

\section{CONFLICTS OF INTEREST}

The authors state that there are no conflicts of interest.

\section{ACKNOWLEDGMENTS}

The authors want to thank Dr. Jose Manuel Piña Gutiérrez who provided the facilities of Rancho "El Rodeo". Moreover, the research grant provided by the Programa de Fomento a la Investigación, through the project "Eficiencia 
energética madre/cría en ovinos de pelo" (PFI: UJATDACA-2015-IA-02).

\section{REFERENCES}

AFRC. 1993. Energy and Protein Requirements of Ruminants. Agricultural and Food Research Council. CAB International, Wallingford, UK.

Aguilar-Hernández, E., A. J. Chay-Canul, A. Gómez-Vázquez, J. G. Magaña-Monforte, F. G. Rios and A. Cruz-Hernández. 2016. Relationship of ultrasound measurements and carcass traits in pelibuey ewes. J. Anim. Plant Sci. 26: 325-330.

Alic-Ural, D. 2016. The use of new practices for assessment of body condition score. Rev. MVZ Córdoba. 21: 5154-5162.

Alapati, A., S. R. Kapa, S. Jeepalyam, S. M. P. Rangappa and K. R. Yemireddy. 2010. Development of the body condition system in Murrah buffaloes: validation through ultrasonic assessment of body fat reserves. J. Vet. Sci. 11: 1-8.

Ayres, H., J. R. M. Ferreira, R. S. Torres-Júnior, C. G. B. Demetrio, C. G. de Lima and P. S. Baruselli. 2009. Validation of body condition score as a predictor of subcutaneous fat in nelore (Bos indicus) cows. Livest. Sci. 123: 175-179.

Azzaro, G., M. Caccamo, J. D. Ferguson, S. Battiato, G. M. Farinella, C. G. Guarnera, G. Puglisi, R. Petriglieri and G. Licitra. 2011. Objective estimation of body condition score by modeling cow body shape from digital images. J. Dairy Sci. 94: 2126-2137.

Broring, N., J. W. Wilton and P. E. Colucci. 2003. Body condition score and its relationship to ultrasound back fat measurements in beef cows. Can. J. Anim. Sci. 83: 593-596.

Chay-Canul, A. J., A. Ayala-Burgos, J. C. Kú-Vera,J. G. MagañaMonforte and L. O. Tedeschi. 2011. The effects of metabolizable energy intake on body fat depots of adult Pelibuey ewes fed roughage diets under tropical conditions. Trop. Anim. Health Prod. 43: 929-936.

Chay-Canul, A. J., R. A. Garcia-Herrera, V. M. Meza-Villalvazo, A. Gomez-Vazquez, A. Cruz-Hernandez, J. G. Magaña-Monforte and J. C. Ku-Vera. 2016. Body fat reserves and their relationship to ultrasound back fat measurements in pelibuey ewes. Ecosist. Recur. Agropecu. 3: 407-413.

Chilliard, Y., F. Bocquier M. Doreau. 1998. Digestive and metabolic adaptations of ruminants to undernutrition, and consequences on reproduction. Reprod. Nutr. Dev. 38: 131-152.

CONAGUA. 2016. Available from: http://www.conagua.gob.mx. [Last accessed on 2016 Jun 25].

Gentry, L. R., D. Thompson, G. T. Jr. Gentry, R. P. Del Vecchio, K. A. Davis and P. M. Del Vecchio. 2004. The relationship between body condition score and ultrasonic fat measurements in mares of high versus low body condition. J. Equine Vet. Sci. 24: 198-203.

Halachmi, I., M. Klopcic, P. Polak, D. J. Roberts and J. M. Bewley. 2013. Automatic assessment of dairy cattle body condition score using thermal imaging. Comput. Electron. Agric. 99: 35-40.

Hussein, H. A., A. Westphal and R. Staufenbiel. 2013. Relationship between body condition score and ultrasound measurement of backfat thickness in multiparous Holstein dairy cows at different production phases. Aust. Vet. J. 91: 185-189.

Jaurena, G., J. M. Moorby, W. J. Fisher and R. Cantet. 2005. Association of body weight, loin longissimus dorsi and backfat with body condition score in dry and lactating Holstein dairy cows. Anim. Sci. 80: 219-223.

Junkuszew, A. and F. Ringdorfer, F. 2005. Computer tomography and ultrasound measurement as methods for the prediction of the body composition of lambs. Small Rumin. Res. 56: 121-125.

Keinprecht, H., M. Pichler, H. Pothmann, J. Huber, M. Iwersen and M. Drillich. 2016. Short term repeatability of body fat thickness measurement and body condition scoring in sheep as assessed by a relatively small number of assessors. Small Rumin. Res. 139: 30-38.

Kenyon, P. R., S. K. Maloney and D. Blache. 2014. Review of sheep body condition score in relation to production characteristics. N. Z. J. Agric. R. 57: 38-64.

McManus, C., S. R. Paiva and R. O. de Araújo. 2010. Genetics and breeding of sheep in Brazil. Rev. Bras. Zootec. 39: 236-246.

Mendizabal, J. A., R. Delfa, A. Arana and A. Purroy. 2011. Body condition score and fat mobilization as management tools for goats on native pastures. Small Rumin. Res. 98: 121-197.

Myers, R. H. 1990. Classical and Modern Regression with Applications. 2nd ed. Duxbury Press, Belmont, California.

Ptáček, M., J. Ducháček, L. Stádník and J. Beran. 2014. Mutual relationships among body condition score, live weight, and back tissue development in meat sheep. Acta Vet. Brno. 83: 341-346.

Quaresma, M., R. Payan-Carreira and S. R. Silva. 2013. Relationship between ultrasound measurements of body fat reserves and body condition score in female donkeys. Vet. J. 197: 329-334.

Russel, A. J. F., J. M. Doney and R. G. Gunn. 1969. Subjective assessment of body fat in live sheep. J. Agric. Sci. 72: 451-454.

Sanson, D. W., T. R. West, W. R. Tatman, M. L. Riley, B. M. Judkins and G. E. Moss. 1993. Relationship of body composition of mature ewes with condition score and body weight. J. Anim. Sci. 71: 1112-1116.

SAS. 2010. Version 9.3 Software. Institute Inc., Cary, North Carolina, USA.

Schröder U. J. and R. Staufenbiel. 2006. Invited review: Methods to determine body fat reserves in the dairy cow with special regard to ultrasonographic measurement of backfat thickness. J. Dairy Sci. 89: 1-14.

Silva, S. R., R. Payan-Carreira, M. Quaresma, C. M. Guede and A. S. Santos. 2016. Relationships between body condition score and ultrasound skin-associated subcutaneous fat depth in equids. Acta Vet. Scand. 58: 62-67.

Taylor, R. 1990. Interpretation of the correlation coefficient: A basic review. J. Diagn. Med. Sonogr. 1: 35-39.

Zulu, V. C., T. Nakao, M. Moriyoshi, K. Nakada, Y. S. Y. Tanaka and W. C. Zhang. 2001. Relationship between body condition score ultrasonographic measurement of subcutaneous fat in dairy cows. Asian Australas. J. Anim. Sci. 14: 816-820. 